\title{
Effectiveness of Criminal Prosecution of Tax Offenses
}

\author{
Mykola Karchevskyi ${ }^{1}$ *[0000-0002-2693-3592], Oleksandr Korystin ${ }^{2,3}$ [0000-0001-9056-5475], \\ Vitalii Komarnytskyi ${ }^{1}$ [0000-0003-1510-2395]
}

\author{
${ }^{1}$ Luhansk State University of Internal Affairs named after E.O. Didorenko, Sievierodonetsk, Ukraine \\ ${ }^{2}$ State Scientifically Research Institute of the Ministry of Internal Affairs, Kyiv, Ukraine \\ ${ }^{3}$ National Security and Defense Council's of Ukraine Inter-Service Research Center into Combating Organized Crime \\ Problems, Kyiv, Ukraine \\ *comcriminal@gmail.com
}

\begin{abstract}
The article focuses on the study of criminal law regulation of tax offenses. Data on threats to the fiscal security of Ukraine are analyzed. Emphasis is placed on the critical threats of avoiding criminal liability for tax offenses and assessing the risks of their spread, and the critical threats are analyzed. The level of risk of spreading threats of avoidance of criminal liability for tax offenses is determined based on the imperfection of the norms of the Criminal Code of Ukraine. It is established that the dominant criminal law measure in this area is an exemption from criminal liability. It is noted that a careful analysis of the effectiveness of such counteraction and the reasons for this state of affairs is limited to practical due to some systemic shortcomings of criminal statistics in general.
\end{abstract}

Keywords: threats, fiscal security, taxes, risk, risk assessment, discharge, decriminalization.

\section{INTRODUCTION}

Ensuring fiscal security requires a thorough awareness of the actual processes in society, the nature of relations in the fiscal sphere, and minimizing the risks of their criminalization. Criminal legislation is one of the key elements of the state mechanism of fiscal security. In the context of social, socio-economic, and political-legal changes requires constant monitoring, thorough research into the shortcomings of legal regulation, adequacy, and validity of criminal law. Therefore, it is necessary to have an adequate strategic vision, objective knowledge of the most significant threats that form the appropriate level of danger and distort fiscal relations in society.

\section{RESEARCH ANALYSIS}

Criminal law regulation in the field of fiscal relations is the subject of research of a large constellation of scientists and practitioners who make hypotheses, substantiate models and forecasts, identify shortcomings of legal norms and their application. This process involves conducting on the appropriate methodological basis of security research of an applied nature, using empirical data not only statistical content (which is not excluded) but also modern risk- oriented approaches, with the development and scientific substantiation of research hypotheses, focusing on their threats and risks distribution [1].

Modern information society needs a new perception of reality, which is formed by understanding several threats and risks of their spread in society [2]. The content of the threat determines the content of risk, and the value of risk is formed from the estimated combination of levels of probability and probability of such a threat. To use such a particular method of cognition, the international standard ISO 31000: 2018 is used, which is also a national Ukrainian standard [3-5].

\section{THE ARTICLE'S OBJECTIVE}

Based on empirical data to analyze the threats of avoidance of criminal liability for violations of tax legislation, to focus on the threats of the Criminal Code of Ukraine; assess the risks $[6,7]$ of the spread of specific threats; identify the most significant threats by the level of risk. Using open data from official statistics to investigate the dynamics of criminal law counteraction to tax evasion to establish the structure of criminal law measures applied by national courts. 


\section{THE RESULTS OF THE STUDY}

The activity of civil society is a guarantee of awareness of social processes, and in combination with measures and support of the state, characterizes the adequacy of the knowledge system [8] on the socio-economic development of modern society.

The Association of Taxpayers of Ukraine, implementing the tasks of strategic analysis in fiscal security, based on a risk-oriented approach, provided qualitative and quantitative empirical data on the risks of threats in the fiscal sphere [9]. As a result, a total of 243 threats in the fiscal sphere were identified, of which 32 characterize the avoidance of criminal liability for tax offenses by the level of risk.

The overall rating of threats to avoid criminal liability for tax offenses (Figure 1) is based on data on the level of risk of the spread of these threats (Table 1).

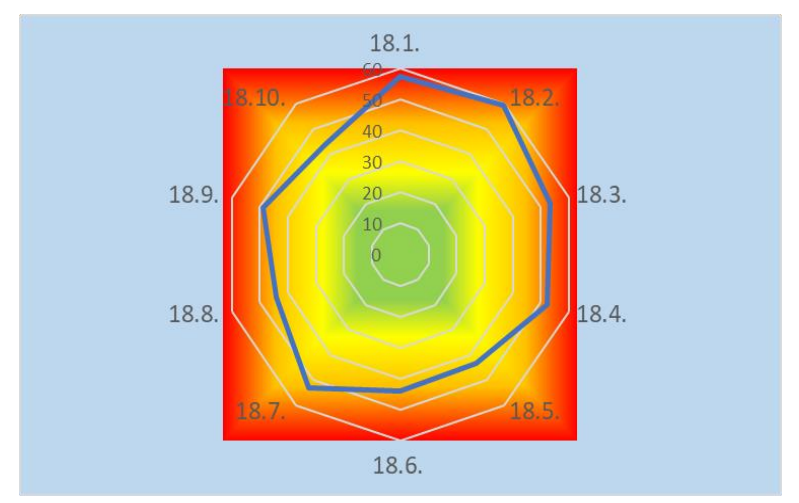

Figure 1 Threat Rating

Thus, from the list of threats of avoidance formed by the level of criminal liability for tax offenses, threats with the highest level of risk are distinguished, which characterizes them as significant and those that require the control of top management, in particular:

- avoidance of criminal prosecution for tax offenses based on imperfection of the Criminal Code of Ukraine $57,54 \%$;

- avoidance of criminal prosecution based on gaps in criminal procedural law $-59,55 \%$;

- avoidance of criminal prosecution based on imperfect tax legislation norms - 53,21\%;

- avoidance of criminal prosecution based on imperfect customs legislation norms $-52,37 \%$;

- avoidance of criminal prosecution based on the inefficient organization of pre-trial investigations $53,02 \%$.
Table 1. Threats in the Field of Fiscal Security

\begin{tabular}{|l|c|}
\hline \multicolumn{1}{|c|}{ Avoidance of criminal liability } & $\begin{array}{c}\text { Risk } \\
\text { Asses }\end{array}$ \\
\hline $\begin{array}{l}\text { 18.Avoidance of criminal liability for tax } \\
\text { offenses }\end{array}$ & 57,10 \\
\hline $\begin{array}{l}\text { 18.1. Avoidance of criminal prosecution for } \\
\text { tax offenses on the basis of imperfection of } \\
\text { the Criminal Code of Ukraine }\end{array}$ & 57,54 \\
\hline $\begin{array}{l}\text { 18.2. Avoidance of criminal prosecution } \\
\text { based on gaps in criminal procedural law }\end{array}$ & 59,55 \\
\hline $\begin{array}{l}\text { 18.3. Avoidance of criminal prosecution on } \\
\text { the basis of imperfect tax legislation norms }\end{array}$ & 53,21 \\
\hline $\begin{array}{l}\text { 18.4. Avoidance of criminal prosecution on } \\
\text { the basis of imperfect customs legislation } \\
\text { norms }\end{array}$ & 52,37 \\
\hline $\begin{array}{l}\text { 18.5. Avoidance of criminal prosecution } \\
\text { based on inefficient activities of the } \\
\text { prosecutor's office }\end{array}$ & 43,43 \\
\hline $\begin{array}{l}\text { 18.6. Avoidance of criminal prosecution on } \\
\text { the basis of inefficient organization of } \\
\text { operational and investigative activities }\end{array}$ & 43,91 \\
\hline $\begin{array}{l}\text { 18.7. Avoidance of criminal prosecution on } \\
\text { the basis of inefficient organization of pre- } \\
\text { trial investigations }\end{array}$ & 53,02 \\
\hline $\begin{array}{l}\text { 18.8. Avoidance of criminal prosecution on } \\
\text { the basis of ineffective consideration of } \\
\text { materials of criminal proceedings in courts }\end{array}$ & 44,23 \\
\hline $\begin{array}{l}\text { 18.9. Avoidance of criminal prosecution } \\
\text { based on inefficient activities of expert } \\
\text { organizations and institutions }\end{array}$ \\
\hline $\begin{array}{l}\text { 18.10. Avoidance of criminal prosecution } \\
\text { based on counteraction to criminal } \\
\text { prosecution }\end{array}$ & 43,56 \\
\hline
\end{tabular}

The further analysis aims to identify some problems in applying the provisions of the Criminal Code of Ukraine on tax offenses (Table 2).

Among the listed indicators that identify threats, according to the level of risk, there are threats related to the imperfection of the Criminal Code. The risk, which is characterized by the general content of the threat - the imperfection of the Criminal Code, is estimated at $62.52 \%$. This level of risk requires this measure to take urgent measures to reduce the risk of its spread.

Along with this, clarifying the problems of application of the norm of Art. 212 of the Criminal Code, there are two additional threats also with a high level of risk:

- absences in the sanctions of Art. 212 in the Criminal Code of Ukraine of criminal punishment in the form of imprisonment $-63,9 \%$; 
- a significant increase in the minimum thresholds for tax evasion $-56,84 \%$.

Table 2. Avoidance of Criminal Liability for Tax Offenses based on the Imperfection of the Criminal Code Norms

\begin{tabular}{|l|c|}
\hline $\begin{array}{c}\text { Avoidance of criminal prosecution } \\
\text { for tax crimes }\end{array}$ & $\begin{array}{c}\text { Risk } \\
\text { assesm }\end{array}$ \\
\hline 18.1.1. decriminalization of illegal acts & 53,62 \\
\hline 18.1.1.1. according to Article 201 & 48,87 \\
\hline 18.1.1.2. according to Article 203 & $\mathbf{6 2 , 0 5}$ \\
\hline 18.1.1.3. according to Article 205 & 52,40 \\
\hline 18.1.1.4. according to Article 207 & 48,47 \\
\hline 18.1.1.5. according to Article 208 & $\mathbf{6 1 , 8 1}$ \\
\hline $\begin{array}{l}\text { 18.1.2. imperfection of the mechanism of } \\
\text { prosecution for tax crimes (Article 212 of } \\
\text { the Criminal Code) in }\end{array}$ & $\mathbf{6 2 , 5 2}$ \\
\hline $\begin{array}{l}\text { 18.1.2.1. absences in the sanctions of Art. } \\
\text { 212 in the Criminal Code of Ukraine of } \\
\text { criminal punishment in the form of } \\
\text { imprisonment }\end{array}$ & $\mathbf{6 3 , 9 0}$ \\
\hline $\begin{array}{l}\text { 18.1.2.2. a significant increase in the } \\
\text { minimum thresholds for tax evasion }\end{array}$ & 56,84 \\
\hline
\end{tabular}

Of some scientific interest is the consideration of trends in criminal law regulation in combating tax evasion (Article 212 of the Criminal Code) in context. The analysis of open sources of statistical information allows the authors to draw the following conclusions:

1) since 2013, there has been a steady trend of reducing the recorded criminal offenses under Art. 212 of the Criminal Code; in 2019, compared to 2013, such offenses were recorded 3.6 times less; $\%$ in 2019) and the indictment (36\% in 2013, 24\% in 2019);

3) a similar trend is observed in the dynamics of court decisions related to the use of Art. 212 of the Criminal Code (figure 2); the total number of persons in respect of whom such court decisions entered into force decreased from 336 in 2013 to 209 in 2019; the vast majority of these court decisions for the entire period under study is related to the release from criminal liability under Part 4. Art. 212 of the Criminal Code; the share of such court decisions tends to increase (65\% in $2013,96 \%$ in 2019)

4) in the case of convictions under Art. 212 of the Criminal Code (figure 3) courts mainly used either a fine (about $70 \%$ ) or release from punishment (about 25\%)

5) the indicator "the sum of unpaid taxes, fees, and other obligatory payments" reflects the losses established within the accounted proceedings; it is necessary to pay attention that in 2013 it made more than four trillion hryvnias in 2019 - decreased almost four times.

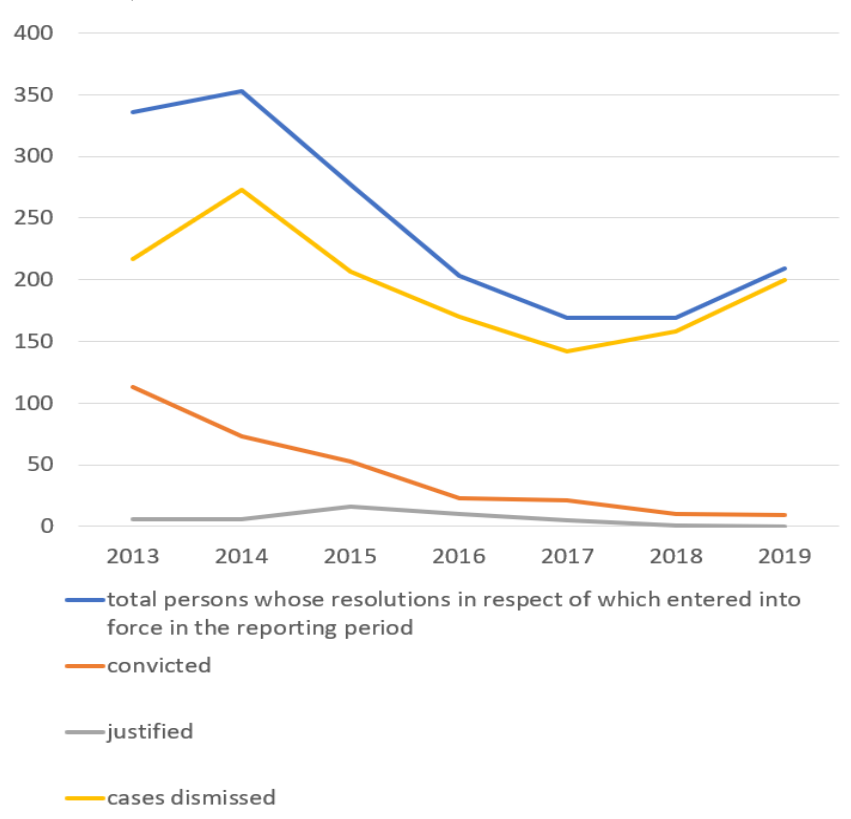

Figure 2 Absolute Data on Adjudications Related to the Application of Article 212 of the Criminal Code

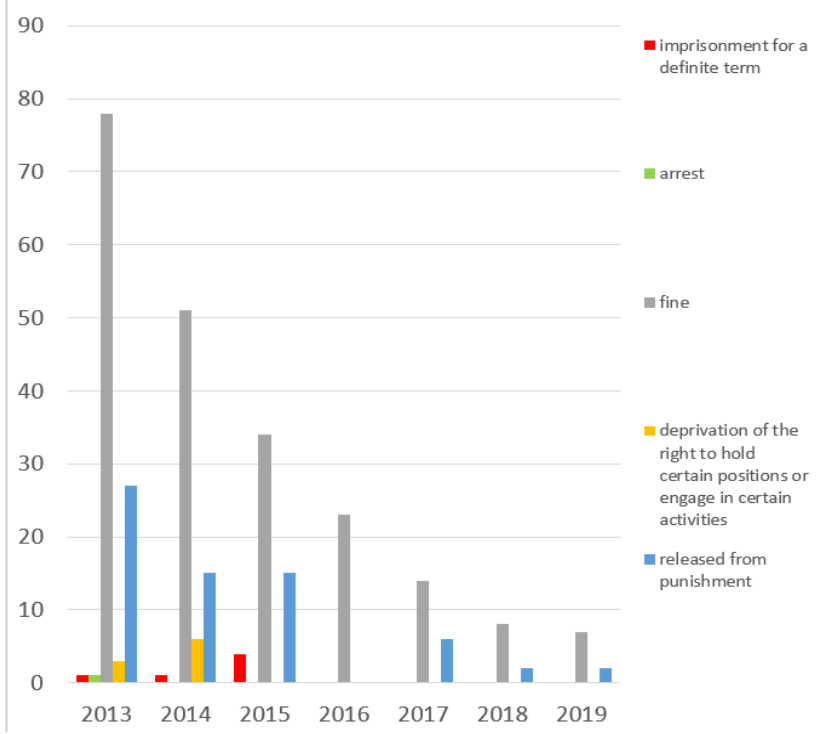

Figure 3 Absolute Data on the Applied Criminal Law Measures (Article 212 of the Criminal Code)

Further detailing of the obtained data is complicated by a systemic factor - the imperfection of the organization of criminal statistics. Thus, it should be recognized that the 
available statistical information does not allow drawing reasonable conclusions about the state of criminal law regulation; it is not possible to integrate data on accounting of offenses and court proceedings; their analysis is of limited effectiveness.

First, it is necessary to pay attention to the difference between the concepts of "recorded proceedings" and "registered proceedings". Because free access is provided only to the number of proceedings in which no decision was made to close based on par in the reporting period. 1 or 2 Part 1 of Art. 284 of the CPC (accounted), it is impossible to answer the most critical questions. The main ones are: what is the reflection of crime in reports to law enforcement agencies about offenses? What are the features of the structure of decisions made by law enforcement agencies depending on the initial qualification? How does law enforcement reform affect the distribution of decisions in registered proceedings?

Second, the unit of measurement in the reports of the Prosecutor General's Office is criminal proceedings. In turn, the reports of the State Judicial Administration relate to the number of persons in respect of whom a decision has been made (conviction, acquittal, closure of proceedings). Moreover, the accounting of proceedings is organized only by article numbers. At the same time, the data in the reports of the State Judicial Administration are submitted by parts of the articles of the Special Part of the Criminal Code. In addition, even if we conditionally compare the number of proceedings and the number of persons against whom a court decision has been made, the question of the year of registration of the proceedings remains open. The fact is that the courts during the year considered those proceedings recorded in the reporting period. It is also impossible to single out such proceedings based on published statistics. Thus, we have a situation where it is unlikely to trace the progress of criminal proceedings [10].

However, despite the limited data of official statistics, it seems possible to draw the following conclusions about the peculiarities of national criminal law in combating tax evasion.

First, the predominant form of criminal law influence in this area is an exemption from criminal liability. Part 4 of Art. 212 of the Criminal Code, which allows exemption from criminal liability if a person, before being prosecuted, paid taxes, fees (mandatory payments), as well as reimbursing the damage caused to the state by their late payment (financial sanctions, fines).

Second, from 2013 to 2019 , there is approximately the same decrease, approximately four times, of the accounted criminal proceedings and the amounts of unpaid taxes established within the criminal proceedings. Analyzing this issue, we do not even consider the change in the value of the national currency. This limited data of statistics, particularly the lack of information on the number of registered (unregistered) proceedings, does not allow reaching a sound conclusion about the following. There is a decrease in tax pressure on the economy, or we have an increase in the shadow and corruption segments.

Third, in the context of the reform of criminal law, the crucial question of the desired model of criminal law regulation in the field of taxation arises. Should the current approach be maintained and criminal law used mainly to exempt from tax liability? Perhaps it is necessary to abandon criminal liability for such criminal offenses altogether? These questions can be answered by obtaining more detailed data, a fundamental change in existing statistical records.

\section{CONCLUSIONS}

Thus, the analysis of threats of avoidance of criminal liability for violation of the tax legislation is carried out. Among other threats, the imperfections of the Criminal Code of Ukraine are estimated at $62.52 \%$, which requires the application of urgent measures to reduce the risk.

According to official statistics, the dominant criminal measure in combating tax evasion is an exemption from criminal liability. This highlights the abolition of criminal liability for the crime under investigation or a radical change in the model of criminal law counteraction to tax evasion.

\section{REFERENCES}

[1] Oleksandr Korystin and Nataliia Svyrydiuk. (2021), “Activities of Illegal Weapons Criminal Component of Hybrid Threats. Proceedings of the International Conference on Economics", Law and Education Research (ELER 2021), vol. 170, 22 march 2021, pp. 86-91, DOI:10.2991/aebmr.k.210320.016

[2] Bek, U. (2000), Obshhestvo riska. Na puti k drugomu modern [Risk society. On the way to another modernity], per. s nem. V. Sedel'niku i N.Fèdorovoj, Progress-Tradicija, Russian.

[3] Review of international standards for management of risiks, available at: http://oppb.com.ua/news/oglyadmizhnarodnyh-standartiv-z-upravlinnya-ryzykamy

[4] Gede Ary Suta Sanjaya, Gusti Made Arya Sasmita and Dewa Made Sri Arsa (2020), "Information Technology Risk Management Using ISO 31000 Based on ISSAF Framework Penetration Testing (Case Study: Election Commission of X City)", International Journal of Computer Network and 
Information Security, vol. 12, no. 4, pp. 30-40, DOI: $10.5815 /$ ijcnis.2020.04.03

[5] Anak Agung Bagus Arya Wiradarma and Gusti Made Arya Sasmita (2019), "IT Risk Management Based on ISO 31000 and OWASP Framework using OSINT at the Information Gathering Stage (Case Study: X Company)", International Journal of Computer Network and Information Security, vol. 11, no. 12, pp. 17-29, DOI: 10.5815/ijcnis.2019.12.03

[6] Faiza Ayub Syed, Kokub Sultan and Ali Javed (2013), "An Enhanced Action Research Approach for Managing Risks in Software Process Improvement", IJMECS, vol. 5, no. 6, pp. 24-30, DOI: 10.5815/ijmecs.2013.06.04

[7] Qi Cheng and Lei Yu (2010), "Operational Mechanism and Evaluation System for Emergency Logistics Risks", International Journal of Intelligent Systems and Applications, vol. 2, no. 2, pp. 25-32, DOI: $10.5815 /$ ijisa.2010.02.04
[8] Korystin, Oleksandr and Svyrydiuk, Nataliia (2021), "Formation of security competences in law enforcement activities", Nauka i Pravookhorona, vol. 1 (51), pp.

191-198, DOI: $10.36486 / \mathrm{np} .2021 .1(51) .20$

[9] Korystin, O.Y. Katamadze, G.S. Nekrasov, V.A. Melnyk, V.I. and etc. (2021), Fiscal Security of Ukraine - Threats, Risks, Vulnerabilities: Strategic vision, Vidavnichij Dim, Gelvetika, LLC, Kherson, Ukraine

[10] Karchevskyi, M.V. V'yunyk, M.V. and Arlanova, O. D. (2020), Kryminalno-pravove rehulyuvannya $v$ Ukrayini: realiyi ta perspektyvy (analitychni materialy) [Criminal law regulation in Ukraine: realities and prospects (analytical materials)], Komis. z pytan prav. reformy, Robocha hrupa $\mathrm{z}$ rozvytku krymin. prava, Pravo, Kharkiv Ukraine 